https://doi.org/10.22364/hssl.26.1.6

\title{
THE LATVIAN HOTEL INDUSTRY: CHALLENGES AND TRENDS
}

\section{Jūlija Mironova}

M. soc.

\begin{abstract}
The hospitality industry worldwide is one of the leading industries in the economy, as well as one of the leading industries by number of employees worldwide. Hospitality industry provides jobs in countries all over the world, as well as in the countries, where unemployment is at a critical level. In Latvia, hospitality industry is a fast-growing sector of the economy. Its successful development is determined by geographically successful location, natural resources, rich cultural and historical heritage, as well as by growth-oriented workforce. The hotel industry in Latvia is expanding quickly by opening new hotels of local and international companies. Due to fast development, the hotel industry is facing different challenges. Being aware of these challenges would help hoteliers to develop their business as customer are waiting. By knowing newest trends in industry, hoteliers would be able to keep their business competitive. The hotel sector is part of the huge hospitality industry, which offers accommodation to travellers. The aim of this article is to study main challenges and trends of the hotel industry in Latvia and to make proposals for hotels based in Latvia. The report focuses on Latvia hotel industry. The motivation behind this conducting study was to develop advice for hotels operators in Latvia, how it is possible to improve their performance based on main trends and future challenges of the hotel industry in Latvia.
\end{abstract}

Keywords: Latvia, hotel, industry, hospitality, trends, challenges

\section{Overview of tourism industry in Latvia}

In the EU in terms of GDP, of employment and of external trade tourism is considered as one of the most important economic activities. Tourism is the largest generator of wealth and employment; it is economic engine for developed and developing economics worldwide. Industry constitutes 11 per cent of global GDP and supports 200 million jobs worldwide (Paulo, 2000). Furthermore, tourism if often being criticised for providing only low-wage and seasonal employment (Cardoso, 2000).

Tourism in Latvia is considered as one of the country's economic development opportunities and priorities service sector and significant source of export revenues, which increases county's gross domestic product. The tourist industry has a huge multiplier effect - its growth stimulates demand for catering, transport, healthcare, entertainment, 
and trade services. According to calculations of satellite accounts of the Latvian Central Statistical Bureau, the share of tourism-specific sectors in total value added in 2010 amounted to 5.3\%. (Framework of Tourism Development in Latvia for 2014-2020, 2014)

In Latvia, the responsible institution for the development and implementation of tourism policy is the Ministry of Economics of the Republic of Latvia. The Law on Tourism determines the main tasks of the Ministry of Economics in the field of tourism. The Investment and Development Agency of Latvia implements the state policy for tourism development, and its main task is the branding of the country as an attractive tourism destination on the international level. (Sectoral policy. Tourism, 2016) Tourism is considered to be one of Latvia's main economic development opportunities, an important source of export revenue and a key contributor to GDP. The tourism sector provided almost 75000 jobs and accounted for 8.5\% of total employment in Latvia in 2014.

Hotels and similar accommodation establishments recorded 2.1 million guests in 2014, an increase of 14\% over 2013 levels. Of these, nearly $70 \%$ were international visitors. International tourist arrivals grew by $20 \%$ to reach 1.8 million in 2014. Five source markets together accounted for $60.9 \%$ of total tourist arrivals - Russia (19\%), Lithuania (14\%), Estonia (10\%), Sweden (9\%) and Germany (9\%). (OECD Tourism Trends and Policies, 2016)

Regarding to the available statistics of Central Statistical Bureau in Latvia, the number of hotels in Latvia is growing every year. Table 1 shows a number of hotels during last 3 years.

Table 1. Number of hotels and other accommodation establishments in Latvia

\begin{tabular}{|l|c|c|c|}
\hline \multicolumn{1}{|c|}{ Total } & 2014 & 2015 & 2016 \\
\hline Hotels and similar establishments & 544 & 563 & 607 \\
\hline $\begin{array}{l}\text { Guesthouses and other short-stay } \\
\text { accommodation }\end{array}$ & 238 & 306 & 316 \\
\hline $\begin{array}{l}\text { Camping grounds, recreational vehicle } \\
\text { parks and trailer parks }\end{array}$ & 17 & 242 & 275 \\
\hline
\end{tabular}

Source: Central Statistical Bureau

Table 1 shows, that total amount of hotels in Latvia is growing every year by approx. $\sim 10 \%$. The other type of accommodation are also increasing in number.

Table 2 shows number of rooms in hotels and other accommodation establishments. 
Table 2. Number of rooms in hotels and other accommodation establishments in Latvia

\begin{tabular}{|l|c|c|c|}
\hline \multicolumn{1}{|c|}{ Total } & 2014 & 2015 & 2016 \\
\hline \multicolumn{1}{|c|}{} & 14873 & 15138 & 15862 \\
\hline Hotels and similar establishments & 11114 & 11970 & 12425 \\
\hline $\begin{array}{l}\text { Guesthouses and other short-stay } \\
\text { accommodation }\end{array}$ & 3563 & 2993 & 3250 \\
\hline $\begin{array}{l}\text { Camping grounds, recreational vehicle } \\
\text { parks and trailer parks }\end{array}$ & 196 & 175 & 187 \\
\hline
\end{tabular}

Source: Central Statistical Bureau

Both of the Tables above and statistic data are showing an increasing amount of both the number of hotels and number of rooms, which can be considered as a sign of growing tourism industry. (Central Statistical Bureau, 2017)

83\% of total amount of overnight stays in Riga belongs to foreign tourists, but in Jūrmala amount is decreasing $-58 \%$. Based on export capability, without Riga, can be highlighted the largest cities in Latvia Jūrmala, Liepāja, Ventspils, Valmiera, Jelgava, Kuldīga, Jēkabpils, Daugavpils etc. (Framework of Tourism Development in Latvia for 2014- 2020, 2014)

Local hotel operators dominate the Latvian hotel market, and the largest of them is SIA "Mogotel" with two hotel brands presented on hotel market - Wellton and Rixwell. There are some international hotel chains in the hotel market in Latvia - Carlson Rezidor Hotel Group and Accor Hotel Group, Kempinski Hotels (Real Estate Market Overview, 2017). Figure 1 shows the distribution of hotels by the number of stars in Latvia.

Figure 1. Distribution of hotels by number of stars in Latvia 2016

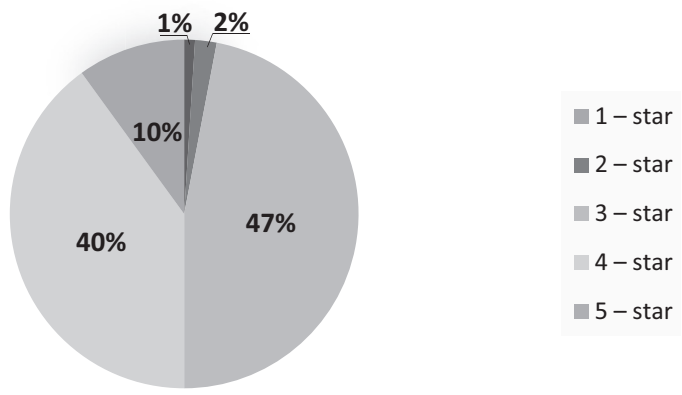

Source: Real Estate Market Overview, 2017

Figure 1 shows how the number of stars distributes hotels in Latvia. The tendency shows that there are mainly 3 star and 4 star hotels in 
hotel market in Latvia, which means that medium segment hotels are very popular. The luxury 5 star hotel segment is much smaller and more exclusive. The 1 star and 2 star hotel segment is extremely small in Latvia.

\section{Trends and Challenges of the Hotel Industry in Latvia}

\section{Technologies in Hotel industry}

It is well known, that in the hotel business rules were always dictated by consumer needs. However, the spread of technology in recent years gives a completely new meaning to the term "consumption driven economy". Technology will change the hotel business to the unknown, moreover, even faster than hoteliers expect it. (Thornton, 2015)

$64 \%$ of U.S. hotel guests mentioned that it is very or extremely important for hotels to continue investing in technology to enhance the guest experience. (Hospitality Oracle, 2016)

Many hoteliers are taking advantage of the advancement of technology by creating hotel homepages for booking and advertising. Even a small hotel, like a bed and breakfast, may have as good a web presence as the largest five-star hotel through a website. (Saxena, 2014)

Technologies are being used to improve efficiencies in the hotel industry. The hospitality industry is the fifth industry with the highest investment in sensors. Based on information from reports and industry news, the investment today is critical to ensure positive customer experiences. (IQ, 2016)

Based on the following information, technology is changing hotel business right now.

Firstly, Millennials (people born around 2000) are becoming important market share, and hotelier's needs are to fight for this market share. These people have completely different habits and expectations regarding communication, service and brand loyalty than hoteliers are used to. According to the survey data, $46 \%$ of millennials mention, that online check-in would motivate them to choose this hotel again (Thornton, 2015). Mobile hotel check-in and checkouts could become the norm soon, enabling staff to focus more on the guest experience. (Carter, 2017)

Secondly, more and more companies are relying on online search platforms such as Google and Booking.com B.V. This trend has created a new challenge - how to become aware of their brand and values? In 2020 , the smartest players in the industry will find ways to communicate their uniqueness to market segments of interest, but now they need to understand their target audience and its desires.

Thirdly, many of major hotel chains have neglected Airbnb and similar alternative hotel service providers, who offer their own vacant apartments 
to guests. At the end of 2014, Airbnb became the world's largest hotel provider of hotel services, measured in rented rooms. This platform is offering rooms in $99 \%$ of countries in the world. Now, hotels have to rethink their business model. Only proactive steps in developing innovative pricing systems and attracting strategic partners will allow current players to keep their business. (Thornton, 2015)

Robotisation could be a serious issue for hotel industry in future years. Millennials, who are becoming main contributors of the hotel industry, are expecting robotisation in everyday life, and accommodation is not an exception. A fully robot-operated hotel already exists - Hen-na Hotel in Sasebo, Japan. Millennials nowadays expect immediate response from the accommodation, so hotels will be forces to use chatbots (compute application with artificial intelligence, what manages to maintain conversations with human users) for immediate response. (Celia, 2016)

However, technologies are fast becoming part of the hotel industry, and hoteliers need to use them to improve their performance and become more attractive to potential customer. Only following this trend, hotels may become competitive enough.

\section{Taxation in Hotel Industry}

Until now, VAT on accommodation services was $12 \%$, but in 2017 , the Latvian Ministry of Finance came up with a proposal to raise this tax from $12 \%$ to $21 \%$, following the recommendation of the World Bank. According to the accommodation enterprises opinion, this action will cause serious damage to the industry and also is a negative signal for the business environment and investments in this sector in Latvia. (Vaidere, 2017)

On March 31, 2017, the Minister of Economics, Arvils Ašeradens, met presidents of largest tourism organisations to discuss the decision of the Ministry of Finance to increase VAT. According to the opinion of the representatives of the industry, this decision is dangerous for the industry: Latvia would lose its competitiveness as a tourism destination; many enterprises will be forced to stop their business activity, which would increase unemployment. Furthermore, it would give a negative impact to the revenues of regional government budget and would make all the investments in recent years in attracting tourists meaningless.

If the plan of increasing of VAT will be implemented, the tax on accommodation in Latvia will be more than twice as high as in Estonia or Lithuania, and three times higher than in Poland. In 2018, all the Baltic States are celebrating the century of the foundation of their Republics. These events will be visited not only by locals, but also by tourists. If Latvia becomes less competitive, visitors will more likely visit Lithuania 
and Estonia, and investments made in Latvia during last years in attracting of tourists will be lost.

The reduced rate of VAT for tourist accommodation services applied in almost all countries - 25 of 28 countries of EU have reduced VAT. For example, in Estonia and Lithuania the tax rate is $9 \%$, in Poland $7 \%$. At present, the full VAT rate of $20 \%$ and $25 \%$ applies to this service only in Denmark, Slovakia and United Kingdom. If the government will raise VAT to $21 \%$, Latvia will become a country with second highest VAT rate in EU. (Ekonomikas ministrija, 2017)

All the representatives of the tourism industry emphasise that in past years significant and targeted work has been done to popularise Latvia not only as a destination, but also as a favourable and safe place for investments. Riga, as a capital of the Baltic States, is proud of its popularity among foreign tourists. "LiveRiga", the Latvian Congress Office and other projects, has promoted it. (Latvijas Viesnīcu un restorānu asociācija, 2017)

\section{Marketing in Hotel Industry}

To develop the hotel industry in Latvia, the main task for new hotels, as well as for the other hotels, is to take care of the increase in the tourist flow - not to redistribute existing guests, but to directly attract new ones. There is a lot of work to be done in the field of marketing, and Riga should be regarded as an attractive destination. Improving marketing strategies of the hotels is already happening hotels are cooperating with travel agencies; they participate in international exhibitions.

A big challenge for the Latvian hotel business is to fill the conditional vacancy in the off-season from October to April. More business tourists, conferences, big events should be attracted to this period. Prices in Riga hotels are still lower than the average in Europe, even lower than in Estonia. Low prices are pleasing tourists, but not so much - industry representatives. It is necessary to create an interesting and good offer for which customers would be willing to pay more. (Krūmina, 2017)

Companies in the hospitality industry should look for innovative way to please market demand. One of the possible ways to please market demand is to adopt travel commerce platforms, innovative mobile and corporate travel technology to service the world's rapidly growing demand. (Costa, 2016)

Some of the true methods of marketing becoming outdated. Email marketing is proven to be one of the most effective ways to communicate with customers and potential guests, but nowadays hotels are facing with difficulties as younger Generation Y considers this type of communication boring. For a new generation, more attractive advertise are smart technologies. (Hub, 2017) 
However, some of the marketing tools are becoming more and more popular. For example, Facebook is used for customers for sharing their experience - positive or negative, with mentioning place they have been. (Na Su, 2015) It depends on the hotel type, how usually hotel is using Facebook. Luxury hotels are more likely using Facebook as relations management tool, rather than as a distribution channel, how it can be used by budget hotels. (Dieck, 2018)

Globalisation bought a new business model, known worldwide as models based on technologies, mobile networks and smartphones. Millennials power these business models, also known as "connected generation". These customers are exposed to marketing more than any generation in the history. (Costa, 2016)

Nowadays, Millennials have shown scepticism towards regular or traditional communicational approaches. These traditional approaches are strongly focused on products and are using strong sell techniques. Millennials are waiting for a relevant, with emotional approach, focused on products characteristics. Information should be provided on different platforms, including mobile applications. (Margarida Custodio Santos, 2016)

\section{New important players at Hotel Market in Riga}

The hotel industry in Latvia is developing very fast. In 2016, room numbers increased by 358 rooms, comparing to 2015. In the past years, large international hotel chains came to the Riga Hotel Market.

In September 2017, Grand Hotel Kempinski Riga started to host its first guests. This international brand opened the first five-star hotel of this brand in Riga at the beginning of autumn. As the General Manager of the Hotel, George Ganchev, mentions, opening a hotel at the end of high season is a challenge for hotel revenues, but it gives opportunities to focus on training of employees. This international company has their own high internal standards to follow (Darzdovska, 2017). The opening of five star hotels in Riga means that hoteliers will face a challenge of attracting more guests to increase the five-star hotel market in Riga. The number of certified five-star rooms in Latvia reached $\mathbf{5 7 1}$ units; this figure is able to meet currents real demand for these type of rooms. Last year, only $4 \%$ of guests chose five-star hotels. (Vigupe, 2017)

The average hotel occupancy indicator in Latvia in 2016 was $44 \%$, but in Riga $-55 \%$. Despite this fact, few hotels are being built, because they become more competitive than hotels that were built 10-15 years ago. New brands like Radisson RED and Hilton Garden Inn come to the market, and they will attract tourists by using modern technology and by being equipped with the latest technology. These hotels will be able to beat old hotel charm and architecture, and in order to compete with new projects, 
old hotels will be forced to lower prices for accommodation. This turn can lead to decrease in the quality of services they provide. (Vigupe, 2017)

\section{Building of Rail Baltica}

Rail Baltica is a greenfield rail transport infrastructure project. A goal of this project is to integrate the Baltic States in the European rail network. The project includes five European Union countries - Poland, Lithuania, Latvia, Estonia and indirectly also Finland. It will connect Helsinki, Tallinn, Pärnu, Riga, Panevežys, Kaunas, Vilnius, and Warsaw. This project is the largest Baltic - region infrastructure project in the last 100 years, and it is planned to build the railway in 10 years. Rail Baltica is a project for passenger and freight traffic, with a total length of $870 \mathrm{~km}$. (Rail Baltica, 2017)

Rail Baltica is going to bring a completely new travel experience to Baltic passengers that cannot be compared to any of the existing means of transportation in the region. Travel time from Riga to Tallinn with a car is approx. 4 hours, but with Rail Baltica, this journey will be only 1 hour 55 minutes long. (Rail Baltica, 2017)

At the end of 2017, it is planned to start the construction of the Radisson Hotel, which will work under brand Red. The hotel will be built in the centre of Riga, near to the shopping centre Origo, next to the location of the Rail Baltica Station. (Poriete, 2017)

\section{Conclusions: Future Challenges and Trends in the Hotel Business in Latvia}

Tourism is considered to be one of Latvia's main economic development opportunities, an important source of export revenue and a key contributor to GDP.

Local hotel operators dominate the Latvian hotel market, and the largest of them is SIA "Mogotel" with two hotel brands presented on hotel market - Wellton and Rixwell. There are some international hotel chains in hotel market in Latvia - Carlson Rezidor Hotel Group and Accor Hotel Group, and Kempinski Hotels. Guests mainly chooses 3-star and 4-star hotels, these medium segment hotels are very popular. Luxury 5 star hotel segment is much smaller and more exclusive. The 1 star and 2 star hotel segment is extremely small in Latvia.

There are mainly the following trends and challenges in the hotel industry in Riga.

New technologies in the hotel industry are becoming more popular and hoteliers have to implement these technologies in everyday hotel life to stay competitive. Nowadays, new generation of guests are waiting for something special and never seen in the field of technology. International 
hotel chains, like Accor Hotel Group and Rezidor Hotel Group are investing in technologies to develop their hotels in Riga and provide expected service. Local hoteliers need to investigate how real it is to compete with international brands on the field of technologies, and how to implement technological progress into the strategy of the hotel.

There is a proposal of the Ministry of Finance in Latvia to increase VAT on accommodation services from $12 \%$ to $21 \%$. According to the opinion of the representatives of the industry, this decision is dangerous for the industry: many enterprises will be forced to stop their business activity, which would increase unemployment. As a result, increasing VAT would give negative impact to the revenues of regional government budgets. Although this proposal is not yet accepted, hoteliers need to implement these changes in their future business plans to become with new strategies based on higher VAT rate. Hotels have options to increase room price or attract more guests to fill the space from lost profit because of the new tax rate.

Nowadays hotels are experiencing significant changes in hotel marketing area. The new generation of the guests are waiting for more modern marketing strategies to get them interested in the products the hotels are offering. For the hotels, it is very important to implement technologies in marketing strategies to become competitive and be able to increase their market share because some true methods are becoming outdated and new customers are waiting for advertisements that are more attractive.

Hotel industry in Latvia is developing very fast. In the past few years, huge international hotel chains came to Latvian hotel market - Kempinski Hotel Group and Accor Hotel Group. The opening of new international hotels in Riga means that hoteliers will face challenges in attracting guests, because international hotels are working by the highest standards. These hotels are able to invest in new technologies and build more attractive and innovative buildings. Local hoteliers need to base their strategy on their strengths and invest in the innovative products for guest satisfaction.

Building of the new transport railway system is huge opportunity for hoteliers in Riga. Rail Baltica is going to bring a completely new travel experience to Baltic passengers that cannot be compared to any of the existing means of transportation in the region. The time of journey from different cities in Estonia, Lithuania and Poland will be even two times shorter than time spent traveling by car. Now, at the end year 2017, it is planned to start the construction of the Radisson Hotel, which will work under brand Red. The hotel will be built in the centre of Riga, near to the shopping centre Origo, next to the location of the Rail Baltica Station. 
Local hoteliers should partly base their strategy of development on this project.

There are many challenges hotel industry in Latvia will face in future years. However, following main trends would make hotel performance successful and lead hotels to long-term development.

\section{REFERENCES}

1. Carter, B. $(2017,03)$. How technology is changing the hotel industry and the impact on guest experiences. Retrieved from deBugged: https://www.rentokil.com/blog/howtechnology-is-changing-the-hotel-industry/\#.Whm3XEqWbIU.

2. Célia Veiga, Margarida Custódio Santos, Paulo Águas, José António C. Santos, (2017) "Are millennials transforming global tourism? Challenges for destinations and companies", Worldwide Hospitality and Tourism Themes, Vol. 9 Issue: 6, pp. 603-616, https://doi.org/10.1108/ WHATT-09-2017-0047.

3. Cardoso C., Ferreira L., "The effects of European economic integration on tourism: challenges and opportunities for Portuguese tourism development", International Journal of Contemporary Hospitality Management, Vol. 12 Issue: 7, pp. 401-409, https://doi.org/10.1108/09596110010347248.

4. Central Statistical Bureau. (2017). Tourism in Latvia.

5. Clampet, J. (2016). www.skift.com. Retrieved from Everything You Wanted to Know About the Hotel Industry's Gripes Against OTAs: https://skift.com/2016/04/25/everything-you-ever-wanted-to-know-about-hotel-industrys-complaints-against-otas/.

6. Jorge Costa, Mónica Montenegro, João Gomes, (2016) "What global trends are challenging tourism organizations and destinations today?: Strategic question overview", Worldwide Hospitality and Tourism Themes, Vol. 8 Issue: 6, pp. 620-624, https://doi.org/10.1108/WHATT-09-2016-0055.

7. Jorge Costa, Mónica Montenegro, João Gomes, (2016) "Global trends challenging tourism organisations and destinations today: What are the likely solutions?", Worldwide Hospitality and Tourism Themes, Vol. 8 Issue: 6, pp. 716-719, https:// doi.org/10.1108/WHATT-09-2016-0057.

8. Darzdovska, I. (2017). Pieczvaigžñu viesnīca Grand Hotel Kempinski Riga. Retrieved from www.dienasbizness.lv:http://www.db.lv/ekonomika/tirdznieciba-un-pakalpojumi/ pakalpojumi/foto-pieczvaigznu-viesnica-grand-hotel-kempinski-riga-466446.

9. Doggrell, K. (2017). Italy outlaws the rate parity. Retrieved from Hotel Management: https://www.hotelmanagement.net/own/italy-outlaws-hotel-rate-parity.

10. Ekonomikas ministrija (2017). Türisma nozares organizācijas: PVN celšana kavēs nozares attīstību. Retrieved from Ekonomikas ministrija: https://em.gov.lv/lv/jaunumi/14467turisma-nozares-organizacijas-pvn-celsana-kaves-nozares-attistibu.

11. Framework of Tourism Development in Latvia for 2014-2020 (2014). Retrieved from http://polsis.mk.gov.lv/view.do?id=4823.

12. Hospitality Oracle. (2016). Retrieved from Creating the Coveted Hotel Guest Experience: https://blogs.oracle.com/hospitality/oracle-hospitality-hotel-guestexperience-research-report. 
13. Hub, R. (2017). Three key online marketing challenges facing hotels. Retrieved from revenue-hub.com: https://revenue-hub.com/online-marketing-hotel-challenges/.

14. IQ, P. 6. (2016). Sensing the future of the Internet of Things.

15. Jill Barthel, S. P. (2015). OTAs-A Hotel's friend or foe? London: HVS.

16. Krūmiṇa, I. (2017). Trawelnews.lv. Retrieved from Jaunais LVRA prezidents uz viesnīcu biznesa nākotni raugās optimistiski: http://travelnews.lv/index.php?m_ id=18545\&i_id=5\&pub_id=104390.

17. Latvijas Viesnīcu un restorānu asociācija. (2017). Retrieved from Nozares organizācijas: PVN celšana tūrismam būs katastrofa: http://www.hotel.lv/lv/1064-nozares-organizacijas-pvn-celsana-turismam-bus-katastrofa.html.

18. M. Claudia Tom Dieck, Timothy Hyungsoo Jung, Woo Gon Kim, Yunji Moon, (2017) "Hotel guests' social media acceptance in luxury hotels", International Journal of Contemporary Hospitality Management, Vol. 29 Issue: 1, pp. 530-550.

19. Na Su, Dennis Reynolds, Bixuan Sun, (2015) “How to make your Facebook posts attractive: A case study of a leading budget hotel brand fan page”, International Journal of Contemporary Hospitality Management, Vol. 27 Issue: 8, pp. 1772-1790.

20. OECD Tourism Trends and Policies (2016). Retrieved from http://www.oecd-ilibrary.org/docserver/download/8515041e.pdf?expires $=1510922337 \& i d=\mathrm{id} \& a c-$ cname $=$ guest $\&$ checksum $=\mathrm{C} 2 \mathrm{~F} 4024560 \mathrm{~B} 40 \mathrm{AE} 093 \mathrm{AB} 54 \mathrm{C} 181 \mathrm{~F} 28 \mathrm{BE} 7$

21. Paulo Rita, (2000) "Tourism in the European Union”, International Journal of Contemporary Hospitality Management, Vol. 12 Issue: 7, pp. 434-436, https://doi. org/10.1108/09596110010347374.

22. Poriete, N. (2017). www.db.lv. Retrieved from Gatavojoties Rail Baltica, pie Origo būvēs jaunu viesnīcu: http://www.db.lv/ekonomika/gatavojoties-rail-baltica-pieorigo-buves-jaunu-viesnicu-461426

23. Rail Baltica - Project of Century. (2017). Retrieved from Rail Baltica: http://www.railbaltica.org/about-rail-baltica/.

24. Real Estate Market Overview (2017). Retrieved from http://www.colliers.com/-/media/files/emea/latvia/research/2017/real_estate_market_overview_2017_lq_sf.pdf?la $=$ en-LV.

25. Margarida Custódio Santos, Célia Veiga, Paulo Águas, (2016) “Tourism services: facing the challenge of new tourist profiles", Worldwide Hospitality and Tourism Themes, Vol. 8 Issue: 6, pp. 654-669, https://doi.org/10.1108/WHATT-09-2016-0048.

26. Saxena, K. A. (2014). Importance of technology in hotel business. Retrieved from www.kunwarasheeshsaxena.com: https:/www.kunwarasheeshsaxena.com/importance-of-technology-in-hotel-business/

27. Sectoral policy. Tourism (2016). Retrieved from https://www.em.gov.lv/en/sectoral policy/tourism/.

28. Trivago. (2017). What's happening with rate Parity in the Hotel industry? Retrieved from Hotel Manager Blog: http://hotelmanager-blog.trivago.com/rate-parity-hotel-industry-status/.

29. Vaidere, I. (2017). Latvijas Avizze. Retrieved from www.la.lv: http://www.la.lv/bezatbildiba-vai-nekompetence-pvn/.

30. Vigupe, V. (2017). Rīgā vairojas viesnīcas. Retrieved from www.varianti.lv: http:// www.varianti.lv/lv/articles/3126. 